\title{
TERTIARY PERFORMANCE, FIELD OF STUDY AND GRADUATE STARTING SALARIES*
}

\author{
by \\ Grace Chia and Paul W. Miller \\ UWA Business School \\ The University of Western Australia
}

\begin{abstract}
This paper analyses data from the University of Western Australia (UWA) Graduate Destination Survey linked to information from the University's Student Records System to explore the determinants of graduates' starting salaries over the years 2002 to 2004. While the details examined also include age, gender, language spoken at home, country of birth, disability status and high school attended, most emphasis is placed on the impact on starting salaries of students' academic performance and their field of study. The analyses show that the main determinant of graduates' starting salaries is the weighted average mark they achieve at university. The salary differentials associated with higher marks in the Australian labour market appear greater than those reported in similar studies of the United States and United Kingdom labour markets. Science graduates are shown to have relatively low starting salaries, casting a shadow over recent suggestions that the supply of this group be increased through lower fee regimes.
\end{abstract}

JEL Codes: J30, J31, J40, J44

Keywords: Starting Salaries, Ability, Field of Study

\footnotetext{
* We wish to thank Kath Williams for data provision, Les Emery, Robert McCormack, Derby Voon, two anonymous referees and an editor for comments, Elisa Birch and Paul Lloyd for helpful advice, and the Australian Research Council and the School of Economics and Commerce at the University of Western Australia for financial support. The views expressed in this paper are those of the authors, and should not be attributed to the University of Western Australia or Graduate Careers Australia.
} 


\section{TERTIARY PERFORMANCE, FIELD OF STUDY AND GRADUATE STARTING SALARIES}

\section{INTRODUCTION}

Graduates' labour market outcomes are a neglected area of research in Australia. While many studies provide assessment of the return to university education (e.g., Preston, 1997), few look behind this aggregate-level return to assess differences in graduate outcomes according to field of study, academic performance at university and pre-university characteristics. Exceptions include Miller and Volker (1983)(1984) and Marks and Fleming (1998a)(1998b). The dearth of research in this area is attributable to the limited data available on graduates' background characteristics.

This study addresses this issue through examination of the starting salaries of undergraduates from the University of Western Australia, and is conducted within a comprehensive framework that permits assessment of the importance to starting salary determination of course studied, study type, tertiary entrance scores, marks at university, type of school attended, birthplace, and gender, among other factors. The value of such analysis is two-fold. First, from an undergraduate's point of view, the study informs on specific qualities and qualifications that translate into higher earnings. This information should serve the student community well. Second, the paper adds to the academic literature in this specialised area of graduates' starting salaries. In particular, the use of information on both tertiary entrance scores, as a measure of early academic achievement, and marks at university, as a measure of later academic achievement, will provide insights into how the arrival of new information might drive out the information content of the earlier test scores (Quiggin, 1999). This should enable a better understanding of the graduate labour market, and indeed of labour markets in general.

The structure of this paper is as follows. Section II provides background information on the economics literature concerning the influences on the salaries of university graduates. Section III outlines the data set used, namely information from the Graduate Destinations Survey linked to the details on the Student Records System at the University of Western Australia. The results of the statistical analysis of starting salaries are presented in Section IV. Section V provides concluding comments. 


\section{CONVENTIONAL WISDOM ON GRADUATES' STARTING SALARIES}

Research into the determinants of the earnings of university graduates has provided information on how test scores and the quality of the university attended affect earnings. It has also informed on the influence of a range of other student and institutional (e.g., type of high school attended) factors, and yielded insights into the screening versus human capital debate. $^{1}$

There are several reasons why one should expect a positive relationship between academic success at university and earnings. First, where competition among applicants is intense, examination scores may be used as a selection criterion and incorporated into the payment system (Boissiere, Knight and Sabot, 1985). Second, in line with human capital theory, differences in academic achievement may translate into different levels of workplace productivity. While seemingly intuitively reasonable, there is mixed evidence on the latter proposition. Wise (1975) suggests that academic achievement is an important determinant of job performance, and Jones and Jackson (1990) report that graduates with higher grades feel better prepared for their first job. However, McClelland (1973) and Baird (1985) have both reported a generally small, positive relationship between traditional academic aptitude and occupational accomplishment, especially in areas requiring creative imagination. Given this range of views, the links between academic achievement at university and labour market outcomes are best seen as an empirical matter.

The empirical relationship between test scores and earnings has been examined for over half a century. A positive association between undergraduate Grade Point Average (GPA) and postBaccalaureate earnings has been reported for almost all fields of education (e.g., James et al., 1989; Weisbrod and Karpoff, 1968; Wise, 1975). In models that contain a more extensive set of test scores, such as in Murnane, Willett and Levy (1995), $12^{\text {th }}$ grade test scores have also been found to be an important determinant of earnings. Moreover, improvements in high school test scores over the years are associated with increases in post-secondary school earnings (Rose, 2006), with these often being more important for women than for men (Murnane, Willett and Levy, 1995; Rose, 2006). Thus, to the extent that education is an

\footnotetext{
${ }^{1}$ Study of graduate starting salaries may also enhance understanding of the processes that may have generated other patterns established in the empirical labour economics literature. For example, it could be used to examine whether the gender pay gap occurs from the time of first appointment, or whether it widens (or possibly narrows) with time in the labour market. This would enable the relevance of the Mincer and Polachek (1978) "intermittent work history" explanation of the gender pay gap to be assessed.
} 
investment in higher earnings capacity, it appears to be a better investment for those individuals who have the ability and motivation to achieve a higher GPA, both at high school and university.

Other than for the early analyses by Blandy and Richardson (1982) and Marks and Fleming (1998a)(1998b) there is no Australian evidence on the direct links between ability and labour market outcomes. Blandy and Richardson (1982) report that IQ is not an important determinant of the earnings of individuals in their mid-twenties. Marks and Fleming (1998a)(1998b) show that early childhood achievements in literacy and numeracy are associated with lower probabilities of becoming unemployed, shorter durations of unemployment and moderately higher earnings among young adults. These analyses were based on measures of achievement provided by standardised tests conducted when the students were 10 or 14 years of age. In view of the findings reported below, and in related research by Birch and Miller (2006a)(2007), which show that the information content for predicting later outcomes of tests taken early in the academic career is far less than that of tests taken later in the academic career, early childhood achievement tests may not be the most useful indicator to use in study of labour market outcomes. ${ }^{2}$

Graduates’ starting salaries have also been shown to be affected by the quality and prestige of the university attended (Callaway, Fuller and Schoenberger, 1996; James et al., 1989; Smart 1988; Hoxby, 1998). Most empirical research in the United States has shown that, compared to attending a public tertiary institution, students from elite private institutions receive a large earnings premium, while students who attended a middle-rate institution receive a smaller earnings premium (Brewer, Eide and Ehrenberg, 1999). However, the more recent evidence suggests a degree of convergence of this school quality premium over time (Murphy and Peltzman, 2004). Moreover, some researchers report that only male graduates receive a school quality premium (Rumberger and Thomas, 1993). ${ }^{3}$

\footnotetext{
${ }^{2}$ Marks and Fleming's (1998b) research has the surprising result that the impact of early childhood achievement on earnings increases with the time since the tests were taken. This suggests that the finding in Section IV, that the Tertiary Entrance Score has no impact on graduates' starting salaries, needs to be augmented with further research into whether this particular outcome changes with time in the labour market.

${ }^{3}$ Stratyer (2002) contends, however, that better measures of school quality would be useful in accurately accessing the quality-earnings relationship. In this regard, there exists only a weak relationship between school resources and student achievement (Hanushek, 1997), though other measures of school quality (e.g., teacher-topupil ratio) have been found to be significantly related to student achievement.
} 
In the United Kingdom, institutional effects do not seem to be as important as other individual factors, with the elasticity of earnings with respect to higher education resources being quite low (Belfield and Fielding, 2001). There does not appear to be any evidence on institutional effects in Australia, other than that reported in Miller and Volker (1983). They report that graduates from the Australian National University, the University of New South Wales, and Monash, Macquarie and La Trobe Universities marginally out-perform their counterparts from other institutions, though the earnings effects were small and varied considerably between males and females.

Looking further back into one’s educational profile, high school institutional effects may also affect earnings. These can be decomposed into a direct effect on earnings and an indirect effect, whereby the choice of tertiary education is influenced. Investigating the direct relationship, Naylor, Smith and McKnight (2002) find that attendance at an independent high school is associated with 3 percent higher earnings compared to students from local area authority schools. This was after controlling for characteristics of the university attended and academic achievement. Naylor et al. (2002) also found that for males the independent high school earnings premium varied with several school characteristics, namely fees and socioeconomic status. It was not, however, affected by the religious affiliation of the school or other school characteristics (such as school size and teacher-to-pupil ratio). Vella (1999) reports that attending a Catholic school in Australia has, at best, a modest direct effect on the hourly rate of pay. Similarly, the analysis by Marks and Fleming (1998b) shows that attendance at a Catholic or Independent school rather than at a government school does not have a direct effect on earnings in Australia.

Starting salaries also appear to vary according to choice of major. Generally, majors in the "hard” and "applied” fields provide a better initial return in the US labour market compared with other majors (James et al., 1989; Rumberger and Thomas, 1993; Smart 1988; Thomas, 2000). Health-related or engineering majors have been found to command a large (35 to 50 percent) premium, whereas the premium associated with a science or maths major is typically smaller (20 and 25 percent), when compared with majors in social science, humanities or education (Rumberger and Thomas, 1993; Thomas, 2000). Miller and Volker's (1983) analysis of 1980 graduates from Australian universities also shows that graduates who 
specialised in health-related, engineering, science and maths areas earned more than graduates in the humanities, especially after adjustment for the likelihood of obtaining employment. ${ }^{4}$

Thus, on the basis of this brief overview, it would be reasonable to expect the university performance score in this study, the Weighted Average Mark (WAM), to be a significant determinant of graduates' starting salaries. Tertiary Entrance Rank (TER), the overall assessment for the completion of Year 12, should also be included in the model of graduates' starting salaries, but one would expect it to have a lesser impact on starting salaries due to the time elapsed since leaving high school. Including information on both WAM and TER in the earnings equation will permit assessment of the screening function of test scores in the labour market (Quiggin, 1999). In particular, if test scores serve only as a screening device, having information on only TER should suffice in the earnings function. Major of study should also be an important determinant of graduate starting salaries in Australia. With a study of graduates from only one university, however, tertiary institutional effects cannot be explored. Nevertheless, the relevance of high school institutional effects to the determination of graduates' salaries can be explored. These will be confined to the examination of school type (Independent, Catholic and government), school size (small, medium and large) and school gender (coeducational, boys and girls) effects.

\section{DATA DESCRIPTION AND MODEL}

The data analysed below are from the Graduate Destination Survey merged with the Student Records System at the University of Western Australia (UWA). The data were merged in this way to enable a more comprehensive account of graduate labour market success. The study relates to graduates who received a Bachelor's degree from the University between 2002 and 2004. These UWA graduates had a first enrolment year ranging from 1991 to 2004.

\footnotetext{
${ }^{4}$ Miller and Volker (1984) extend this analysis and apply the Wiles (1974) test in a comparison of the starting salaries of Science and Economics graduates employed in occupations related to their study, and their counterparts employed in occupations not related to their study. Only for male science graduates was there evidence in favour of human capital theory. Lang and Kropp (1986) claim that this implies only that the skills signaled or acquired are equally productive in study-related and non-study-related jobs.
} 


\section{The Graduate Destination Survey}

The aim of the Graduate Destination Survey (GDS) is to take a snapshot of what recent graduates are doing in terms of their post-graduation activities, and to gather information about their higher education experience (Graduate Careers Australia 2005). The survey code of practice and recommended methodology for the GDS are provided by Graduate Career Australia (GCA), but the responsibility for conducting the survey lies with the universities. At UWA, this survey is conducted jointly by Planning Services and the Careers Centre in Student Services. Graduates have the option of completing an online version of the GDS, facilitated by GCA, or completing the hardcopy. The cohort of students analysed in this study were surveyed between 2003 and 2005, as UWA commences the initial mail out of the survey four to six weeks after convocation. Two follow-ups are made. The first of these comes in the form of an email or postcard sent seven weeks after the initial mail out. The second follow-up, with the GDS form attached, occurs eleven weeks after the initial mail out. Occasionally, there would be a third follow-up.

Table 1 shows the national and UWA response rate to the GDS, together with the number of UWA graduates reporting starting salaries. UWA's response rate falls below the national level, although both sets of response rates are reasonably low. While the 50.6 percent overall response rate for UWA results in slightly more than 6000 surveys over 2003 to 2005, only around two-fifths of these meet the key criteria of being for graduates who completed a Bachelor's degree and who have valid starting salary data. Further, only domestic students who replied to the survey were included in the analysis. This gives a potential sample of 2216 . Records with information missing on key variables in the analysis were deleted. This reduced the potential sample set from 2216 to 2143.

Table 1: Summary of the breakdown of the raw dataset

\begin{tabular}{l|lll|l}
\hline Year & $\mathbf{2 0 0 3}$ & $\mathbf{2 0 0 4}$ & $\mathbf{2 0 0 5}$ & Total \\
\hline National Response Rate & $56.8 \%$ & $56.1 \%$ & $58.0 \%$ & $57.0 \%$ \\
UWA Response Rate & $48.6 \%$ & $48.6 \%$ & $54.7 \%$ & $50.6 \%$ \\
Completed Surveys & 1627 & 2212 & 2214 & 6053 \\
Bachelor's degree & & & & \\
$\quad$ - with starting salaries & 730 & 774 & 1118 & 2622 \\
- and domestic students & 658 & 639 & 919 & 2216 \\
- and complete data & 627 & 626 & 890 & $\mathbf{2 1 4 3}$ \\
\hline
\end{tabular}

Source: Hammond and Emery (2005), UWA Graduate Destination Survey. 
An important issue regarding response rates relates to respondents being representative of the entire population. If non-respondents do not match respondents on various characteristics, response bias arises, and results inferred from the analysis may not be representative of the behaviour of the underlying population (Groves, 1989). Hence, if the GDS suffered from such a bias, it would flow through into the statistical analyses presented below.

A study was conducted to examine the non-responders to the 1996 GDS (Guthrie and Johnson, 1997). Thirty-seven universities contributed data to the 1996 GDS, and fourteen of these agreed to take part in the Non-Response Survey (NRS). While UWA was one of the universities that contributed data to the GDS, it did not take part in the NRS. Hence, the comments below relate to non-UWA universities, and whether they will generalise to UWA is a moot point. However, it seems reasonable to assume that they will.

The NRS study found that non-respondents, as a group, did not entirely match respondents. Females were slightly over-represented in the GDS. The other characteristics where discrepancies between respondents and non-respondents arose were age, level of qualification, fee-paying status, and mode of attendance, but differences between the two groups on most of these were relatively minor. However, it was found that the respondent group was an adequate reflection of the non-respondent group in terms of both field of study and full-time work force status. Accordingly, Guthrie and Johnson (1997) concluded that GDS figures are likely to be "reasonable indicators of the full-time labour market position of the population of graduates from that relevant cohort.”

Using the Guthrie and Johnson (1997) report, and given that the GDS methodology and code of practice have not changed much since the NRS was conducted, it would be reasonable to assume that the data described in the next sub-section suffer from minimal survey bias. Accordingly, no techniques for estimating, adjusting for and/or minimizing the non-response bias are applied in this analysis. This approach follows the standard practice in this area.

A further issue is the extent to which the results of a study of the graduates in one university in Western Australia might carry across to other labour markets. Around 80 percent of the graduates in the sample worked in Western Australia. Incorporating information on the state in which the graduate worked did not add to the explanatory power of the model. Moreover, these were few differences in the aggregate level indicators of the Western Australian and 
national labour markets over 2002-2004. For example, while the unemployment rate in WA over this period declined from 6.3 to 4.8 percent, the national rate fell from 6.4 to 5.7 percent. Average weekly earnings of full-time adults in WA increased from $\$ 912$ to $\$ 1010$, while at the national level they rose from $\$ 913$ to $\$ 1,006$. Hence, while the WA economy was stronger towards the end of the data period, the differences appear modest, especially in terms of earnings.

\section{Model overview}

The model used is a standard earnings equation, with the dependent variable being the log of annual gross salary as reported in the survey.

$$
\ln (\text { salary })_{i}=\alpha+\beta X_{i}+\varepsilon_{i}
$$

The set of explanatory variables (X) included in (1) can be classified into three broad categories, namely personal characteristics, educational profile and employment. Brief descriptions of the main variables follow.

The dependent variable is the natural logarithm of annual gross wage/salary, as reported in the Graduate Destination Survey. It has a mean of 10.214 (\$27 282). There is considerable variation in starting salaries, with the standard deviation being 0.908 .

Table 2 provides details on the personal characteristics included in the preferred specification of the model. While a more extensive list of variables was initially considered, many potential regressors did not contribute to the explanatory power of the equation and are therefore not considered here. Information on these variables is available from the authors upon request. The following personal characteristic variables are fairly standard, though two require further comment. First, the age variable is entered into the model in exponential (Gompertz) form, specifically $e^{-0.1^{*} A g e}$. This follows the research of Borland and Suen (1994) and Le, Miller, Heath and Martin (2005), which suggests this functional form is superior in the study of young workers. Second, the age at migration variable for immigrants from non-Englishspeaking countries (NESB) reflects Chiswick and Miller's (2007) finding that there are ages at arrival where the English proficiency of immigrants from NESB does not differ significantly from that of immigrants who arrived as infants. The threshold in this regard 
ranges from 5 to 9 years. Hence, a dichotomous variable was created to distinguish immigrants who arrived as young children ( $<7$ years) from other immigrants to capture the "Native-like" language proficiency that the former group might be expected to acquire.

Table 2: Description and summary statistics of the personal characteristics explanatory variables

\begin{tabular}{lcc}
\hline Variable description (names used in the analysis are given in italics) & Mean & Std. Dev. \\
\hline $\begin{array}{l}\text { Age: } \\
\text { Continuous variable for graduates' Age on } 30 \text { April in the survey year. It is }\end{array}$ & 23.545 & 4.777 \\
entered into the model in exponential form, $e^{-0.1^{*} \text { Age }}$. & & \\
$\begin{array}{l}\text { Country of birth: } \\
\begin{array}{l}\text { Dummy variable for graduates born in mainly non-English-speaking countries } \\
(N E S B) \text {. }\end{array}\end{array}$ & 0.143 & 0.350 \\
$\begin{array}{l}\text { Omitted category - graduates born in Australia or in English-speaking countries. } \\
0.857\end{array}$ & 0.350 \\
$\begin{array}{l}\text { Age at migration } x \text { Country of birth: } \\
\begin{array}{l}\text { Dummy variable for graduates from NESB who arrived in Australia before they } \\
\text { were 7 years of age. }\end{array}\end{array}$ & 0.057 & 0.233 \\
\hline
\end{tabular}

As noted Section II, field of education, characteristics of high school, student status at university and academic achievement have all been shown to have an impact on earnings ( $\mathrm{Li}$ and Ding, 2006; Miller and Volker, 1984; Brewer, Eide and Ehrenberg, 1999; Naylor, Smith and McKnight, 2002; Wise 1975). A description of the representation of these factors employed in current analysis and summary statistics are included in Table 3. 
Table 3: Description and summary statistics of the educational profile explanatory variables

Variable description (names used in the analysis are given in italics) Mean $\quad$ Std. Dev.

Weighted average mark (WAM):

Continuous variable for the WAM of the course. By default, this is the WAM $69.308 \quad 7.180$

component of their undergraduate degree.

Course type:

Dummy variable for graduates who have either completed a Postgraduate 0.063

Bachelor's or Graduate Diploma.

Omitted category - graduates who have completed only an Undergraduate 0.937

Bachelor's course.

Attendance type:

Dummy variable for graduates who studied on a part time basis, defined as 0.265

those whose aggregate EFTSU for all the units studied was less than 0.75 .

Omitted category - graduates who studied on a full time basis at University.

$0.735 \quad 0.441$

TER dummy:

Dummy variable for graduates with a TER unknown.

$0.198 \quad 0.399$

Omitted category - graduates whose TER is known.

$0.812 \quad 0.399$

High school:

Dummy variable for graduates with their high school unknown. Therefore, for

$0.411 \quad 0.492$

these graduates, high school size, type and co-educational status are unknown.

High school size:

Dummy variable for graduates who went to a:

Small high school with 100 or fewer students in Year 12.

$0.074 \quad 0.261$

Omitted category - graduates who did not attend a small high school.

$0.926 \quad 0.261$

High school type:

Dummy variable for graduates who went to a(n):

Independent high school.

$0.174 \quad 0.379$

Catholic high school.

0.134

0.341

Omitted category - graduates who went to a government high school.

0.281

0.450

Field of study (means in parentheses):

Dummy variable for graduates who completed a degree in:

Architecture (0.041), Arts (0.131), Commerce (0.147), Computer and Maths Science (0.017),

Dentistry (0.019), Economics (0.023), Engineering (0.170), Health Science (0.012), Law (0.078),

Medicine (0.070), Music (0.017), Psychology (0.008), Social Work (0.022).

Omitted category - graduates who completed a degree in Science (0.239).

Finally, earnings will presumably be affected by the type of employment the graduate finds.

"Employment Type" is the last category of explanatory variables. A description and summary statistics are included in Table 4. 
Table 4: Description and summary statistics of the employment type explanatory variables

\begin{tabular}{llr}
\hline Variable Description (names used in the analysis are given in italics) & Mean & Std. D \\
\hline Year of work: & & \\
\hline Dummy variable for graduates who were surveyed in: & 0.415 & 0.493 \\
2005. & 0.292 & 0.455 \\
2004. & 0.293 & 0.455
\end{tabular}

Hours of work:

Continuous variable denoted by the natural logarithm of average hours worked 3.401

0.662

per week.

Employer:

Dummy variable for graduates employed in the:

Government (Federal, State or Local) sector.

$0.233 \quad 0.423$

Education (Private or Public) sector.

$0.092 \quad 0.290$

Other sectors, namely self-employed or employed in the not-for-profit $0.086 \quad 0.281$ sector.

Omitted category - graduates who are employed in the Private sector.

$0.588 \quad 0.492$

Employment length:

Dummy variable for graduates who were not permanent or anticipated being in

0.323

0.468

their current employment for fewer than 12 months or who were unsure about their current tenure.

Omitted category - graduates who were permanent or anticipated being in their

$0.677 \quad 0.468$

current employment for more than 12 months.

Study status:

Dummy variable for graduates who were studying at the time of the survey.

$0.279 \quad 0.448$

Omitted category - graduates who were not studying anymore.

$0.721 \quad 0.448$

Occupation (means in parentheses):

Dummy variable for graduates who were:.

Managers or administrators (0.021), Natural and physical science professionals (0.073), Building and engineering professionals (0.160), Accounting professionals (0.065), Business and Information professionals (0.087), Health professionals (0.098), Education professionals (0.068), Social, arts and miscellaneous professionals (0.060), Associate professionals (0.094), Other occupations (0.023), Advanced clerical and service workers (0.031).

Omitted category - graduates who were an intermediate or elementary clerical, sales and service worker (0.217).

It is apparent from Table 3 that the typical graduate in the sample has completed a standard undergraduate Bachelor's degree programme. Three quarters of the graduates had studied on a full-time basis. For over four-fifths of the sample, there is valid information on the students' TER. All respondents in the sample have, by construction, information on the WAM at university, and the average of this is almost 70. Most of the graduates are employed in professional occupations (see Table 4), and most (59 percent) are in the private sector, although almost one-quarter are in the government (non-education) sector. This considerable 
heterogeneity of the students' educational and employment experiences is related to their starting salaries in the following section.

\section{RESULTS}

Table 5 lists selected results from the model of the determinants of graduate starting salaries. As noted above, the initial estimations involved a more extensive specification of the estimating equation, and details are available from the authors. However, many of the model terms were statistically insignificant. A general-to-specific modelling strategy was employed (Hendry, 2000). There are several limitations of this methodology (see Krolzig and Hendry, 2001), the most important of which seems to be path dependence (see Pagan, 1987), and the lack of clear guidelines on the best way to proceed when simplifying the general model. A multiple search path approach (Hoover and Perez, 1999; Krolzig and Hendry, 2001) revealed that no matter what reasonable path was taken in terms of rejecting insignificant variables, there was a unique outcome in terms of the preferred simplified model, namely the model of Table 5.

Table 5: Selected least squares estimates of the determinants of graduate starting salaries $^{(a)}$

\begin{tabular}{|c|c|c|c|c|c|}
\hline Variables & Coef. & $\mathbf{t}^{\prime \mathbf{s}^{(\mathrm{b})}}$ & Variables & Coef. & $\mathbf{t}^{\prime}$ (b) $^{(\mathbf{b})}$ \\
\hline Constant & 6.944 & $(34.35) * * *$ & & & \\
\hline & & & Small & -0.118 & $(-1.81) *$ \\
\hline \multicolumn{2}{|l|}{ Personal Characteristics } & & Independent & -0.072 & $(-1.52)$ \\
\hline Age [ $\left.\exp ^{-0.1 \times A g e}\right]$ & -3.503 & $(-4.96) * * *$ & Catholic & -0.072 & $(-1.87) *$ \\
\hline NESB & -0.156 & $(-2.43) * *$ & & & \\
\hline $\begin{array}{l}\text { NESB Arrived as } \\
\text { Young Child }\end{array}$ & 0.126 & $(1.76) *$ & $\begin{array}{l}\text { Employment 1ype } \\
2005 \text { Intake } \\
2004 \text { Intake }\end{array}$ & $\begin{array}{l}0.097 \\
0.018\end{array}$ & $\begin{array}{l}(3.21) * * * \\
(0.60)\end{array}$ \\
\hline Educational Profile & & & Hours worked & 0.875 & $(24.22) * * *$ \\
\hline WAM & 0.007 & $(4.12) * * *$ & Other sector & -0.098 & $(-1.63)$ \\
\hline Course Type & 0.074 & $(1.69) *$ & Not Permanent & -0.098 & $(-2.97) * * *$ \\
\hline Part-time Attendance & 0.032 & $(1.11)$ & Studying & -0.066 & $(-1.94) *$ \\
\hline TER unknown & -0.114 & $(-2.35) * *$ & Occupation Included $^{(\mathrm{c})}$ & & \\
\hline High school & & & Course Type Included $^{(\mathrm{c})}$ & & \\
\hline unknown & -0.048 & $(-1.30)$ & & & \\
\hline Adjusted $\mathrm{R}^{2}$ & & & 0.629 & & \\
\hline F-statistic & & & 85.28 & & \\
\hline Breusch-Pagan $\chi^{2}$ & & & 2780.93 & & \\
\hline Sample Size & & & 2143 & & \\
\hline
\end{tabular}

Notes:

(a) coefficients reported with heteroscedasticity-corrected ' $t$ ' statistics in parentheses.

(b) *, ** and $* * *$ denotes significance at the $10 \%, 5 \%$ and $1 \%$ level respectively.

(c) = The estimating equation included dichotomous variables for 11 occupations and 13 course types. Results are presented in Table 8. 
The model presented in Table 5 has a high $\mathrm{R}^{2}$ by the standards of the typical cross-sectional earnings equation (see Preston, 1997). This is especially noteworthy given that the data for the analysis are from a single tertiary institution.

There are two main groups of results in Table 5: those covering variables that are common in earnings functions (e.g., age, birthplace, hours worked), and those relating to information that is seldom incorporated into earnings functions (e.g., WAM, TER, course of study). In the first instance, results pertaining to variables about which there is already reasonably good information are examined, mainly to establish that there is a solid basis for the empirical analysis of the more novel variables.

The Table 5 results are consistent with much of what is known about labour market outcomes in Australia. Age was entered in the model in exponential form (specifically $\exp ^{-0.1 \times A g e}$ ). The partial effect of age on starting salaries, evaluated at 21 years, is 4.3 percent. At 25 years the partial effect is 2.9 percent. Age could be an indication of a graduate's previous labour market experience. It may also exert an effect on earnings, independent of work experience, through the evolution of physiological and psychological characteristics (Pencavel, 1991).

The results for the birthplace variables also follow the recent literature concerning the operation of the Australian labour market (e.g., Maani, 1994). Thus, graduates from mainly English-speaking countries (ESB) have starting salaries similar to the native born. Graduates born abroad in non-English-speaking background (NESB) countries have starting salaries a statistically significant 14 percent $^{5}$ less than ESB or native-born graduates, ceteris paribus. However, the earnings differential associated with the NESB graduates differs according to the immigrants' age at migration, with those who arrived as young children having salaries in the immediate post-graduation period the same as the native born. ${ }^{6}$

The relationship between starting salaries and hours worked is highly significant (' $\mathrm{t}$ ' $=24.22$ ). While starting salaries increase with hours worked, the results show that a 1 percent increase in hours worked is associated with a 0.875 percent increase in starting salaries. This implies

\footnotetext{
${ }^{5}$ Following Halvorsen and Palmquist (1980), this is calculated by (e coefficient on dummy variable -1$) \times 100$.

${ }^{6}$ Both Maani (1994) and Kler (2005) found that young individuals from an ESB did not have statistically different labour market outcomes from their native-born counterparts, while those from a NESB had relatively unfavourable outcomes.
} 
that the labour supply schedule is backward bending, which is consistent with analysis of the earnings of another group of labour market entrants, namely immigrants (see Chiswick and Miller, 2007b). ${ }^{7}$

Neither gender nor disability proved to be significant in this study of graduates from UWA. ${ }^{8}$ Miller and Volker (1987) also report that there was little evidence of wage discrimination on the basis of sex in the youth labour market. These findings have potential to assist in the understanding of the sizable gender differential reported in the more general studies of earnings in Australia. Specifically, Mincer and Polachek (1978) have argued that the sizable gender gap is due to inadequate controls for women's intermittent labour market activity. This should not be a factor in the study of starting salaries. The Table 5 findings, therefore, appear to add weight to the Mincer and Polachek (1978) argument.

Hence, the variables included in this analysis of graduates' starting salaries that have been part of recent analyses of earnings in Australia are associated with effects on earnings reasonably similar to those reported in the more general studies. There is nothing atypical about the determinants of the earnings of graduates in this regard, and hence the information should provide a useful basis for the detailed analysis of the role of academic accomplishments and related educational background on graduate starting salaries that follows.

Most interest in this analysis is on the WAM and subject type variables. Initially, the WAM was included in the estimating equation in quadratic form. However, the squared WAM term was statistically insignificant, and so only the linear term appears in the preferred model. With a relatively strong positive impact on earnings (' $\mathrm{t}$ ' $=4.12$ ), a one-mark increase in WAM is associated with a 0.68 percent increase in initial earnings for the graduate. How this translates into monetary terms is documented in Table $6 .^{9}$

\footnotetext{
${ }^{7}$ The apparent premium for workers who work fewer hours in Australia is probably due to the mandatory casual loading of 20 percent required under Section 871 of the Workplace Relations Act 1996. Wooden and Bora (1999) show that casual workers earn around 6 percent more than other employees when controlling for human capital variables, demographic characteristics and job characteristics.

${ }^{8}$ The insignificance of the disability variable could be associated with measurement issues: the variable may pick up disabilities affecting studies that do not impact on employment outcomes.

${ }^{9}$ At UWA, $[0,50)$ is equivalent to a Fail $(\mathrm{F}),[50,60)$ is equivalent to a Pass $(\mathrm{P}),[60,70)$ is equivalent to a Credit (CR), $[70,80)$ is equivalent to a Distinction (D) and $[80,100)$ is equivalent to a High Distinction (HD).
} 
Table 6: The change in starting salaries with grades achieved at university

\begin{tabular}{lccc}
\hline WAM & Grade at UWA & $\begin{array}{c}\text { Projected mean starting } \\
\text { salary (nearest \$) }\end{array}$ & Increment from previous grade \\
\hline 45 & Fail & $\$ 23131$ & - \\
55 & Pass & $\$ 24755$ & $\$ 1624$ \\
65 & Credit & $\$ 26492$ & $\$ 1737$ \\
75 & Distinction & $\$ 28352$ & $\$ 1860$ \\
85 & High Distinction & $\$ 30342$ & $\$ 1990$ \\
\hline
\end{tabular}

To put the Table 6 figures in perspective, the gender wage gap in the adult labour market is typically reported as being 10-15 percent. This is equivalent of a 20-point difference in WAM. Thus, the 'WAM salary differential' is about twice the size of the gender wage gap in Australia. Similarly, each additional year of study in the Australian labour market is associated with around 8 percent higher earnings. Hence, the difference in the earnings of a "marginal" student (WAM of 50) and a "top" student (WAM of 85) is the equivalent of around three extra years of schooling. Clearly, having good grades matters when it comes to a graduate’s starting salary.

Tests were also conducted to see if the earnings of some groups (distinguished by demographic characteristics, field of study and occupation) were relatively more sensitive to WAM. For honours graduates, including their honours WAM did not add any information value. There were also no differences picked up for gender or course of study and occupational groups, though the latter two sets of results may be due to the small sample size within each selection category. However, employers appeared to be more sensitive to WAM for graduates from a NESB. A 1-point increase in WAM was associated with a 1.7 percent increase in starting salaries for graduates from a NESB, compared to a 0.5 percent increase for all other graduates. Moreover, this differential of almost 1.3 percentage points between these two groups was found to be significant at the 5 percent level. Projected mean salaries for NESB graduates and all other graduates are depicted in Table 7.

Table 7: Projected mean salary for NESB graduates and all other graduates

\begin{tabular}{cccccc}
\hline \multirow{2}{*}{ WAM } & UWA Grade & \multicolumn{2}{c}{ NESB graduates } & \multicolumn{2}{c}{ All other graduates } \\
\cline { 3 - 6 } & & $\begin{array}{c}\text { Difference from } \\
\text { a Pass }\end{array}$ & $\begin{array}{c}\text { Projected Mean Starting Salary } \\
\text { (nearest } \$ \text { ) }\end{array}$ & $\begin{array}{c}\text { Difference from } \\
\text { a Pass }\end{array}$ \\
\hline 55 & Pass & & $\$ 23715$ & $\$ 25079$ & \\
65 & Credit & $\$ 4475$ & $\$ 28190$ & $\$ 26265$ & $\$ 1186$ \\
75 & Distinction & $\$ 9,795$ & $\$ 33510$ & $\$ 27507$ & $\$ 2428$ \\
85 & High Distinction & $\$ 16118$ & $\$ 39833$ & $\$ 28808$ & $\$ 3729$ \\
\hline
\end{tabular}


When the WAM was 59, the projected mean starting salaries were the same for the two groups. High achieving NESB graduates with a HD average could earn around \$12K more than all other graduates who achieved the same grade. Even NESB graduates with a D average could earn $\$ 7 \mathrm{~K}$ more than all other graduates with the same results. This suggests that there are substantial gains in the graduate labour market for NESB graduates from increasing their academic performance at university. This result has appeal from the perspective of the recent media attention over the English skills of some university graduates: WAM appears to be a better signal for the NESB group or, and perhaps more likely, a higher WAM is associated with a broader set of competencies of NESB students.

Two further tests were conducted. The first involved examining the relationship summarised in Table 5 using quantile regression. This will show if the impact of the WAM varies across the distribution of starting salaries. The impact of the WAM on median starting salaries will also serve as a test of robustness of the Table 5 results. ${ }^{10}$ This analysis revealed that the impact of WAM is relatively large at the first and second deciles of the distribution of starting salaries, is reasonably constant (at around 0.004) from the third to the eighth deciles, inclusive, and that the WAM was an insignificant regressor at the ninth decile. This pattern of effects for test scores is similar to that reported for the impact of university entrance scores on university academic performance by Birch and Miller (2006a). It implies that the least squares estimates may be sensitive to outliers, and suggests some caution in using the point estimates presented, though the main conclusions of this study are unaffected.

The second test involved the omission of the occupation variables. Part of the labour market advantages of superior academic achievements at university may come about through access to better occupations, and this restricted specification will enable the coefficient on the WAM variable to capture these gains. This change to the specification resulted in an increase in the impact of the WAM by about 25 percent. Again, this suggests that the point estimates are sensitive to the specification of the model, though the main conclusions discussed above carry over to this supplementary analysis.

\footnotetext{
${ }^{10}$ The least absolute deviation estimator provides an alternative summary of the central location of the distribution of starting salaries that is less sensitive to outlier observations, such as those that are often associated with misreported salaries.
} 
The positive relationship between test scores and earnings evident from Table 5 is consistent with evidence for the UK and US labour markets. For example, Naylor, Smith and McKnight (2002) report that UK graduates with a first-class degree earned 4 percent more than those with a upper-second-class degree, while those with lower-second-class and third-class degrees earned 6 percent and 10 percent less, respectively. Rumberger and Thomas (1993) report that a one-point increase in GPA (on a 0-4 scale) leads to a 3 percent increase in starting salaries for US graduates. As each ten-points increase in the WAM can be viewed as the broad equivalent of a one-point improvement in the GPA, and the third-class and first-class outcomes in the British system can be considered as the bounds on "marginal" and "top" student, these results suggest that starting salary differentials associated with academic results are more pronounced (up to twice as important) in the Australian graduate labour market than in the US and UK.

TER was not a significant regressor in the model presented here. Moreover, it was still not significant (' $t$ ' $=0.57$ ) when WAM was omitted from the model. This suggests that the role for TER is limited only to the sorting of students across the various courses at university. It was, however, statistically significant when regressed against earnings in the absence of other controls (other than for the year of graduation and hours worked variables). Even in this instance, however, the TER variable lost statistical significance (at the 5 percent level) when the WAM was included in the model. This suggests that the TER does not have a screening function for labour market success in the broader model of the determinants of starting salaries considered here, and even in a restricted model of labour market success, the information content of the TER is superseded by the information content of the WAM. This suggests it has limited signalling capacity for later labour market success.

The course type variable distinguishes graduates who only receive an undergraduate degree from those who have either completed another postgraduate Bachelor's degree or a Graduate diploma. Significant at the 10 percent level, that additional qualification is associated with a 7.4 percent increase in terms of starting salaries. This evidence is consistent with a human capital interpretation of the education process.

Variables for course studied and occupation were included in the estimating equation to enable a comprehensive assessment of the variations in graduates' starting salaries. Most of 
these were found to be significant at the conventional levels. Table 8 provides a ranking of the most financially rewarding fields of study and occupations.

Table 8: Ranking of the most financially rewarding fields of study and occupations

\begin{tabular}{ll|ll}
\hline $\begin{array}{l}\text { Field of Study } \\
\text { (Compared to Science graduates) }\end{array}$ & $\begin{array}{l}\text { Occupation } \\
\text { (Compared to Intermediate Service, Clerical and Sales staff ) }\end{array}$ \\
\hline Dentistry & $103.7 \%$ more* & Natural and Physical Science Professionals & $39.1 \%$ more* \\
Music & $35.4 \%$ more* & Business and Information Professionals & $31.5 \%$ more* \\
Health Science & $26.7 \%$ more* & Managers and Administrators & $31.0 \%$ more* \\
Computer Science & $23.7 \%$ more* & Health Professionals & $30.5 \%$ more* \\
Law & $22.8 \%$ more* & Building and Engineering Professionals & $25.5 \%$ more* \\
Commerce & $18.7 \%$ more* & Social, Arts and Miscellaneous Professionals & $20.0 \%$ more* \\
Social Work & $17.4 \%$ more* & Associate Professionals & $15.4 \%$ more* \\
Engineering & $16.0 \%$ more* & Education Professionals & $9.1 \%$ more \\
Medicine & $12.0 \%$ more & Advanced Clerical and Service Workers & $7.3 \%$ more \\
Economics & $11.1 \%$ more & Accounting Professionals & $6.8 \%$ more \\
Arts & $10.9 \%$ more* & Other occupations & $15.2 \%$ less \\
Psychology & $2.9 \%$ more & & \\
Architecture & $1.5 \%$ more & &
\end{tabular}

* denotes significance at the $5 \%$ level.

Consistent with analysis by Guthrie (2005), dentistry provides the highest immediate earnings returns while Architecture, Psychology and Science provide the least in terms of starting salaries. Compared to the omitted category of Science graduates, graduates from dentistry earn more than double in starting salaries, ceteris paribus.

It is important to bear in mind when interpreting these findings, however, that any subject premium may not show up in the year subsequent to graduation. For example, Belfield and Sloalle (1998) report that a degree in Economics produces a better than average return for individuals in the labour market after six years. Moreover, the apparently low returns associated with the law and medicine fields of study (only 23 percent and 12 percent more than science, respectively) may be due to institutional reasons, and subject premiums in these fields of study will almost certainly show up in later years. The higher starting salary associated with music could be due to two factors: the small sample size and the use of interviews and auditions for the selection of students into the music course, which could imply that these graduates are associated with above average levels of unobservables that are associated with labour market success. 
Professionals have higher starting salaries than non-professionals, and these starting salary differentials are mostly statistically significant at the 1 percent level. It was also found that the natural and physical science professionals had the highest starting salaries, earning 39 percent more than the intermediate service, clerical and sales staff benchmark group, ceteris paribus. While accounting and education professionals were the least paid professionals, the difference in their starting salaries compared to the intermediate service, clerical and sales staff benchmark group were not found to be statistically significant. ${ }^{11}$

These findings for type of work are consistent with related literature, with Kler (2005) reporting that graduates in Australian managerial and professional jobs earn the most. Assuming graduates work in a field related to their major, Pencavel (1991) also reports that in the US, natural science and engineering graduates earn more than humanities or education graduates. $^{12}$

The final set of variables that are relatively unique to the present study are admission basis (TER unknown), school type and school size. These have modest effects on starting salaries. Graduates in the “TER unknown” category (typically mature-age students ${ }^{13}$ ) have 11 percent lower earnings, other variables the same, which is an earnings effect similar to that of students who attended small schools. Students from Catholic schools who attended university are shown to have earnings 7 percent lower than their government school counterparts ${ }^{14}$, though this effect is significant only at the 10 percent level.

\footnotetext{
11 The quantile regression results for the field of study variables have several patterns. The impacts of Law, Commerce and Dentistry across the distribution of starting salaries, for example, is U-shaped, while those for Engineering and Social work are higher at the first few deciles of the distribution than they are at the upper end of the distribution. The typical pattern across the distribution of the coefficients of the occupation variables in the quantile regression is U-shaped, though for some occupations (e.g., Natural and Physical Science Professionals, Business and Information Professionals, Managers and Administrators) the effects are more pronounced at the upper tail than at the lower tail, while for other occupations (e.g., Health Professionals) the opposite holds.

${ }^{12}$ The results for the self-employment, currently studying and expected job duration variables are consistent with
expectations. As the findings are peripheral to the main focus of this study, they are not discussed further here.

${ }^{13}$ At UWA, applicants seeking admission fall into two groups (UWA Handbook, 2006). If their TER was received in the 5 years prior to admission, the applicant would be considered as a group one candidate and would compete on the basis of their TER. This TER could be received from the Tertiary Entrance Examination (TEE) in Western Australia, the equivalent interstate examination, the International Baccalaureate Diploma program or the New Zealand university entrance exam. All other applicants are considered group two applicants, and are considered by the relevant faculty selection committee on an individual basis. They could be admitted based on any of the standard qualifications listed above. Otherwise, any other overseas school qualifications, Technical and Further Education (TAFE) or tertiary results would be evaluated. Hence, they would have an unknown TER.

${ }^{14}$ The point estimate for Independent schools is also 7 percent, though this effect is not statistically significant.
} 
There are several interpretations of the "TER unknown” effect. First, it could represent a mature-age student effect. However, given that the results were standardised for age, perhaps it is the 'non-traditional' pathway to graduate status of this group that is being penalised. Second, it could represent graduates who did not meet the initial requirements to UWA the first time and transferred from TAFE or another tertiary institution. Hence, compared to their group one counterparts (see footnote 13), they were not as competitive and competent in securing a position at UWA, and it is this set of factors which is being identified indirectly, and which is being penalised.

The effects associated with type of high school attended are interesting, even though they are not strong statistically. They accord reasonably well with what is known about the impact of high school attended on labour market outcomes in Australia (see Marks and Fleming, 1998b; Vella, 1999).

Significant at the 10 percent level, attending a small high school is associated with 11.8 percent lower starting salaries, ceteris paribus. The reason for this may be two-fold. First, school size is an important predictor of a school's curriculum (Monk, 1987). Thus, larger schools may have the scale and resources to offer a more comprehensive curriculum with more value-added. Second, many of Western Australia's small schools are located in the nonmetropolitan area. Hence, this variable might also be picking up an adjustment effect into the metropolitan way of life.

\section{CONCLUDING COMMENTS}

The analyses reported above show that the labour market is rather discerning when it comes to paying graduates. Even graduates from a single university, which has a reasonably high entrance standard, and one might have thought a homogeneous student body, differ tremendously in their starting salaries. However, knowledge of a graduate's academic accomplishments at university, course studied, and occupation of employment goes a long way to understanding the salary they will command in their first job. The students' Tertiary Entrance Ranks have little bearing on their salaries upon graduation. Similarly, the type of high school they attended (Government, Catholic, Independent) has little influence on salaries in their first job, though the evidence available indicates that students who went to 
Government schools do relatively well in this regard. The $\mathrm{R}^{2}$ in the model of graduates' starting salaries was 0.63 , which is quite high for cross-sectional analyses of earnings.

These findings are interesting for several reasons. First, they should be of interest to university students, as, to some extent at least, marks at university, course studied and occupation of employment are outcomes that are under the control of the individual student. Second, the statistical insignificance of the TER shows that the labour market responds to the most recent information that is available: data on academic achievements at university apparently drives out the information content of the TER. This is consistent with findings in Birch and Miller (2006a)(2007), to the effect that the information content of the TER is superseded by marks in the early years of university study when marks in later years of university study are investigated.

The WAM of students range from around 50 to close to 100, though average marks above 80 are certainly the exception rather than the rule. Still, moving from being a "marginal" student (WAM of 50) to being a "top" student (WAM of 80) is associated with 20 percent higher starting salaries. As a benchmark, each additional year of education in Australia is, on average, associated with about 8 percent higher earnings. Hence, the findings in this paper suggest that ability and/or effort can drive up earnings the equivalent of around 2.5 years of schooling. This is a very high earnings advantage, and compared to it, the earnings effects typically associated with gender, birthplace and even English language proficiency and computer skills come across as being relatively modest.

Holding constant academic achievements (both at university and at high school, though the latter is inconsequential in the analyses), students who enter Computer Science, Health Science, Law and Commerce earn about 10 percent more than those who graduate in Economics and Arts. In turn, Economics and Arts degree holders have starting salaries around 10 percent more than Science graduates. Much has been made in the media about the drift from Science at universities. These analyses suggest that this is likely to be little more than a reaction to poor market prospects. In this case, attempts to increase the supply of graduates through lowering fees in likely to be counterproductive in the long run.

Graduates' starting salaries vary by up to 40 percent according to the occupation in which they work. Natural and Physical Science Professionals are at the top of the occupational 
salary hierarchy, followed by Business and Information Professionals, Managers and Administrators, and Health Professionals. Occupations which attract relatively low salaries are the Intermediate and Advanced Clerical and Service Workers. Graduates who are in the latter occupations are likely to be over-educated, and this is why they are in receipt of relatively low salaries.

This study could be extended to include graduates from other universities. A nationwide study of starting salaries of graduates from Australian universities would enable university characteristics to be included as another set of explanatory variables. Studies that have included the characteristics of university attended (e.g., Belfield and Fielding, 2001; James et al., 1989; Miller and Volker, 1983; 1984) have reported that these are significant determinants of earnings. This research should, however, simultaneously include study of the impact of university performance, if possible.

Attempts should also be made to extend this type of study beyond the analysis of starting salaries. Following a cohort of graduates for up to a decade would enable so much more to be learned about the operation of the graduate labour market, provided that sample attrition rates are reasonable (see Marks and Fleming, 1998a; 1998b). Such data collection is beyond the scope of individual researchers, however.

Finally, the findings in this study, that academic accomplishments at university, field of study and occupation of employment are the strongest predictors of starting salaries, provide the best advice to undergraduates wondering how to maximise their starting salary. So if anyone wants to get that piece of paper (a degree), get it not only in the "correct" field of study, but with marks as high as possible. Then seek to be employed in professional occupations. That way, he/she can look forward to a nice, large number on the other piece of paper-his/her first pay cheque. 


\section{REFERENCES}

Baird, L., (1985). “Do Grades and Tests Predict Adult Accomplishment?”, Research in Higher Education, Vol. 23, No. 1, pp. 3-85.

Belfield, C. and Fielding, A., (2001). "Measuring the Relationship Between Resources and Outcomes in Higher Education in UK”, Economics of Education Review, Vol. 20, No. 6, pp. 589-602.

Belfield, C. and Sloalle, P., (1998). “Graduate Salaries: How Well Do Economics Graduates Fare in the Labour Market”, RES Newsletter, Vol. 101, pp. 7-8.

Birch, E. and Miller, P., (2006a). “The Impact of HECS Debt on Australian Students’ Tertiary Academic Performance”, Education Research and Perspectives, Vol. 33, No. 1, pp.132.

Birch, E. and Miller, P., (2006b). "Student Outcomes at University in Australia: A Quantile Regression Approach”, Australian Economic Papers, Vol. 45, No. 1, pp.1-17.

Birch, E.R. and Miller, P, (2007). "A National Study of Student Outcomes at University”, mimeo, Business School, The University of Western Australia.

Blandy, R. and Richardson, S., (1982). "The Fate of the Class of '71: A Preliminary Analysis”, Australian Bulletin of Labour, Vol. 8, No. 4, pp. S1-S46.

Boissiere, M., Knight, J. and Sabot, R., (1985). "Earnings, Schooling, Ability and Cognitive Skills”, The American Economic Review, Vol. 75, No. 6, pp. 1016-1030.

Borland, J. and Suen, A., (1994). “The Experience-Earnings Profile in Australia”, Economic Record, Vol. 70, No. 208, pp. 44-55.

Brewer, D., Eide, E. and Ehrenberg, R., (1999). "Does it Pay to Attend an Elite Private College”, The Journal of Human Resources, Vol. 34, No.1, pp. 104-123.

Callaway, R., Fuller, R. and Schoenberger, R., (1996). “Gender Differences in Employment and Starting Salaries of Business Majors during the 1980s: The Impact of CollegeAcquired Characteristics”, Research in Higher Education, Vol. 37, No. 5, pp. 599-614

Chiswick, B. and Miller, P. (2007b). "Matching Language Proficiency to Occupation: The Effect on Immigrants’ Earnings”, IZA Discussion Paper No. 2581, IZA, Germany.

Graduate Careers Australia., (2005), About Graduate Careers Australia, [Online], Graduate Careers Australia. Available from: http://www.graduatecareers.com.au/content/view/full/40 [15 March 2006].

Groves, R., (1989). Survey Errors and Survey Costs, Wiley, New York.

Guthrie, B. and Johnson, T., (October 1997), Study of Non-Response to the 1996 Graduate Destination Survey, [Online], Department of Employment, Education, Training and Youth Affairs. Available from: 
http://www.dest.gov.au/archive/highered/eippubs/eip9710/front.htm\#contents [2 April 2006].

Guthrie, B., (2005), Graduate Destinations 2004, Graduate Careers Australia, Australia.

Halvorsen, R. and Palmquist, R., (1980). "The Interpretation of Dummy Variables in Semilogarithmic Equations”, American Economic Review, Vol. 70, No. 3, pp.474475.

Hammond, S. and Emery, L., (2005). Why Ask Me That?, University of Western Australia, Australia.

Hanushek, E., (1997). "Assessing the Effects of School Resources on Student Performance: An Update”, Educational Evaluation and Policy Analysis, Vol. 19, No. 2, pp. 141164.

Hendry, D., (2000). "Epilogue: The Success of General-to-Specific Model Selection”, in Econometrics: Alchemy or Science? Essays in Econometrics Methodology, new edition. ed. D. Henry, Oxford University Press, Oxford, pp. 467-490.

Hoover, K. and Perez, S., (1999). "Data Mining Reconsidered: Encompassing and the General-to-Specific Approach to Specification Search” The Econometrics Journal, vol 2, No. 2, pp. 167-191.

Hoxby, C.M., (1998). 'The Return to Attending a More Selective College: 1960 to the Present', mimeo, Department of Economics, Harvard University, USA.

James, E., Alsalam, N., Conaty, J. and To, D., (1989). "College Quality and Future Earnings: Where Should You Send Your Child to College?”, American Economic Review, Papers and Proceedings, Vol. 79, No. 2, pp. 247-252.

Jones E. and Jackson, J., (1990). “College Grades and Labor Market Rewards”, The Journal of Human Resources, Vol. 25, No. 2, pp. 253-266.

Kler, P., (2005). "Graduate Overeducation in Australia”, Education Economics, Vol. 13, No. 1, pp. 47-72.

Krolzig, H. and Hendry, D., (14 June 2001), Refuting Criticisms, [Online], Timberlake Consultants Ltd, Available from: http://pcgive.com/pcgets/index.html [2 September 2006].

Lang, K. and Kropp, D., (1986). "Human Capital versus Sorting: The Effects of Compulsory Attendance Laws”, Quarterly Journal of Economics, Vol. 101, No. 3, pp. 609-624.

Le, A.T., Miller, P.W., Heath, A. and Martin, N., (2005). "Early Childhood Behaviours, Schooling and Labour Market Outcomes: Estimates from a Sample of Twins", Economics of Education Review, Vol. 24, No. 1, pp. 1-17. 
Li, F. and Ding, X., (2006). Effects of Minor, Class Rank, and Matched Job on the Starting Wages of Graduates: An Improvement of the Wiles Test, Institute of Economics of Education, Peking University, Working Paper.

Maani, S., (1994). “Are Young First and Second Generation Immigrants at a Disadvantage in the Australian Labor Market?”, International Migration Review, Vol. 28, No. 4, pp. 865-882.

Marks, G. and Fleming, N., (1998a). "Factors Influencing Youth Unemployment in Australia: 1980-1994”, Longitudinal Surveys of Australian Youth, Research Report Number 7, Australian Council for Educational Research, Melbourne.

Marks, G. and Fleming, N., (1998b). "Youth Earnings in Australia 1980-1994: A Comparison of Three Youth Cohorts", Longitudinal Surveys of Australian Youth, Research Report Number 8, Australian Council for Educational Research, Melbourne.

McClelland, D., (1973). “Testing for Competence Rather than for Intelligence”, American Psychologist, Vol. 28, No. 1, pp. 1-14.

Miller, P. and Volker, P., (1983). "Starting Salaries and Destinations of Graduates in Australia”, Bureau of Labour Market Research, Conference Paper No. 14.

Miller, P. and Volker, P., (1984). "The Screening Hypothesis: An Application of the Wiles Test”, Economic Inquiry, Vol. 22, No. 1, pp. 121-127.

Miller, P. and Volker, P., (1987). “The Youth Labour Market in Australia: A Survey of Issues and Evidence", Centre for Economic Policy Research, The Australian National University, Discussion Paper No. 17.

Mincer, J. and Polachek, S., (1978). "Women's Earnings Reexamined”, Journal of Human Resources, Vol. 13, No. 1, pp. 118-134.

Monk, D., (1987). “Secondary School Size and Curriculum Comprehensiveness”, Economics of Education Review, Vol. 6, No. 2, pp. 137-150.

Murnane, R., Willett, J. and Levy, F., (1995). “The Growing Importance of Cognitive Skills in Wage Determination”, The Review of Economics and Statistics, Vol. 77, No. 2, pp. 251-266.

Murphy, K. and Peltzman, S., (2004). “School Performance and the Youth Labor Market”, Journal of Labor Economics, Vol. 22, No. 2, pp. 299-327.

Naylor, R., Smith, J. and McKnight, A., (2002). "Why is there a Graduate Earnings Premium for Students from Independent Schools?”, Bulletin of Economic Research, Vol. 54, No. 4, pp. 315-339

Pagan, A., (1987). “Three Econometric Methodologies: A Critical Appraisal”, Journal of Economic Surveys, Vol. 1, No. 1, pp. 3-24. 
Pencavel, J., (1991). “Higher Education, Productivity, and Earnings: A Review”, Journal of Economic Education, Vol. 22, No. 4, pp. 331-360.

Preston, A., (1997). “Where are We Now With Human Capital Theory in Australia?”, The Economic Record, Vol. 73, No. 220, pp. 51-78.

Quiggin, J., (1999). "Human Capital Theory and Education Policy in Australia”, Australian Economic Review, Vol. 32, No. 2, pp. 130-144.

Rose, H., (2006). “Do Gains in Test Scores explain Labor Market Outcomes?”, Economics of Education Review, Vol. 25, No. pp. 430-445.

Rumberger, R. and Thomas, S., (1993). "The Economic Returns to College Major, Quality and Performance: A Multilevel Analysis of Recent Graduates," Economics of Education Review, Vol. 12, No. 1, pp. 1-19.

Smart, J., (1988). “College Influences on Graduates” Income Levels”, Research in Higher Education, Vol. 29, No. 1, pp. 41-59.

Stratyer, W., (2002). “The Returns to School Quality: College Choice and Earnings”, Journal of Labor Economics, Vol. 20, no, 3, pp. 475-503.

Thomas, S., (2000). "Deferred Costs and Economic Returns to College Major, Quality and Performance", Research in Higher Education, Vol. 41, No. 3, pp. 281-313.

University of Western Australia Handbook. (14 June 2006), Undergraduate Admission Eligibility, [Online], University of Western Australia. Available from: http://handbooks.uwa.edu.au/undergraduate/poliproc/UndergraduateAdmission?childf $\underline{x=0 n}$ [26 September 2006].

Vella, F., (1999). "Do Catholic Schools Make a Difference? Evidence from Australia”, Journal of Human Resources, Vol. 34, No. 1, pp. 208-224.

Weisbrod, B. and Karpoff, P., (1968). "Monetary Returns to College Education, Student Ability and College Quality”, The Review of Economics and Statistics, Vol. 50, No. 4, pp. 491-197.

Wiles, P., (1974). "The Correlation between Education and Earnings: The External-Test-Not Content Hypothesis (ETNC)”, Higher Education, Vol. 3, No. 1, pp. 43-58.

Wise, D., (1975). “Academic Achievement and Job Performance”, American Economic Review, Vol. 65, No. 3, pp. 350-366.

Wooden, M. and Bora, B., (1999). "Workplace Characteristics and Their Effect on Wages: Australian Evidence”, Australian Economic Papers, Vol. 38, No. 3, pp. 276-289. 